\title{
Glutamate ameliorates copper-induced oxidative injury by regulating antioxidant defences in fish intestine
}

\author{
Jun Jiang ${ }^{1,2,3}$, Xiao-Yun Wu ${ }^{1,2}$, Xiao-Qiu Zhou ${ }^{2,3}$, Lin Feng ${ }^{2,3}$, Yang Liu ${ }^{2,3}$, Wei-Dan Jiang ${ }^{2,3}$, Pei Wu ${ }^{2,3}$ \\ and $\mathrm{Ye} \mathrm{Zhao}^{1,2_{*}}$ \\ ${ }^{1}$ College of Animal Science and Technology, Sichuan Agricultural University, Chengdu 611130, People's Republic of China \\ ${ }^{2}$ Animal Nutrition Institute, Sichuan Agricultural University, Chengdu 611130, People's Republic of China \\ ${ }^{3}$ Fish Nutrition and Safety Production University Key Laboratory of Sichuan Province, Sichuan Agricultural University, \\ Chengdu 611130, People's Republic of China
}

(Submitted 26 September 2015 - Final revision received 8 March 2016 - Accepted 23 March 2016)

\section{Abstract}

The objective of this study was to determine the protective effect of glutamate (Glu) in Cu-induced oxidative injury in fish intestine in vivo and enterocytes in vitro. The results indicated that exposure to $6 \mathrm{mg} / \mathrm{l} \mathrm{Cu}$ for $72 \mathrm{~h}$ induced the production of reactive oxygen species, thereby increasing protein oxidation and lipid peroxidation in enterocytes of grass carp in vitro. Cells exposed to Cu alone resulted in a significant increase in lactate dehydrogenase release, which is accompanied by depletions of antioxidants, including total superoxide dismutase (T-SOD), glutathione S-transferase (GST), glutathione reductase (GR), anti-superoxide anion (ASA), anti-hydroxy radical (AHR) activities and GSH content. Pre-treatment with Glu remarkably prevented the toxic effects of $\mathrm{Cu}$ on the T-SOD, GST, GR, AHR, and ASA activities and GSH content in enterocytes. However, $\mathrm{Cu}$ induced an adaptive increase in the activities of catalase and glutathione peroxidase (GPx). Glu supplementation further increased GPx activity in enterocytes. Interestingly, the experiment in vivo showed that Glu pre-supplementation significantly elevated SOD, GPx, GST, GR, ASA and AHR activities, as well as GSH content. Further results showed that pre-treatment with Glu could alleviate Cu-induced oxidative injury by elevating antioxidant enzyme activities through regulating the expression of NF-E2-related nuclear factor 2 (Nrf2) mRNA. Together, these results indicated that Glu could attenuate Cu-induced cellular oxidative damage in fish intestine, likely mediated through Nrf2 signalling pathways regulating mRNA expressions of antioxidant enzyme genes and synthesis of GSH.

Key words: Glutamate: Copper: Oxidative injury: Antioxidants: NF-E2-related nuclear factor 2: Intestine

L-Glutamate (Glu) is a non-essential amino acid with versatile functions in animal physiology and metabolism ${ }^{(1)}$. Glu has an important role in the amino acid metabolism through its conversion to $\alpha$-ketoglutarate or other amino acids, including alanine, aspartate, ornithine and proline in intestine ${ }^{(2,3)}$. Thus, Glu can serve both locally inside enterocytes and through the production of other amino acids in an interorgan metabolic perspective $^{(2)}$. In addition, Glu is a key transamination partner and is required for the synthesis of GSH, which is an important component in the defence against oxidative stress ${ }^{(4)}$. Our previous studies demonstrated that dietary Glu supplementation increased intestinal anti-superoxide anion (ASA), anti-hydroxy radical (AHR), glutathione reductase (GR), catalase (CAT) and total superoxide dismutase (T-SOD) activities, and GSH content in grass carp Ctenopharyngodon idella ${ }^{(5)}$, improved antioxidant capacity and regulated antioxidant-related signalling molecule expression of fish enterocytes ${ }^{(6)}$. Sivakumar et $a l .{ }^{(7)}$ reported that Glu alleviated isoproterenol-induced oxidative stress in rats by increasing antioxidant enzyme activities and GSH content from exogenous Glu. These results suggested that Glu could offer protection during intestinal oxidative stress.

$\mathrm{Cu}$ is known for its essentiality for living organisms, including fish, which is required for maintaining cellular function and acting as a cofactor for a number of key metabolic enzymes ${ }^{(8,9)}$. Nevertheless, $\mathrm{Cu}$ is one of the most important pollution-causing metals, because it is commonly released into the environment through industrial wastes and used in the form of copper

Abbreviations: AHR, anti-hydroxy radical; AKP, alkaline phosphatase; ASA, anti-superoxide anion; CAT, catalase; DMEM, Dulbecco's Modified Eagle's Medium; Glu, glutamate; GPx, glutathione peroxidase; GR, glutathione reductase; GST, glutathione S-transferase; LDH, lactate dehydrogenase; MDA, malondialdehyde; MTS, 3-(4, 5-dimethylthiazol-2-yl)-5-(3-carboxymethoxyphenyl)-2-(4-sulfophenyl)-2H-tetrazolium; Nrf2, NF-E2-related nuclear factor 2; OD, optical density; PC, protein carbonyl; ROS, reactive oxygen species; SOD, superoxide dismutase.

* Corresponding author: Y. Zhao, fax +86 288629 1010, email zhye3@foxmail.com 
sulphate as algaecide, fungicide, bactericide and herbicide. In fish culture systems, $\mathrm{Cu}$ is regularly used in the form of copper sulphate $\left(\mathrm{CuSO}_{4}\right)$ to control algal blooms and aquatic macrophyte infestations ${ }^{(16)}$. Recently, aquatic organisms may suffer from exposure to $\mathrm{Cu}$ concentrations that might be ten to fifty times higher than the required concentrations ${ }^{(10)}$. The danger of $\mathrm{Cu}$ is aggravated by their almost indefinite persistence in water because they cannot be destroyed biologically but are only transformed from one state to another ${ }^{(11)}$. Also, high concentrations of waterborne $\mathrm{Cu}$ can be toxic, because perturbations in $\mathrm{Cu}$ homoeostasis result in oxidative stress and increased free-radical production ${ }^{(12-14)}$. The intestine is very sensitive to a wide range of stressors ${ }^{(15)}$. The recent reports show that the intestine is a major target for waterborne $\mathrm{Cu}$ toxicity in both freshwater and seawater fish ${ }^{(16-18)}$. Although $\mathrm{Cu}$ uptake is via gills, $\mathrm{Cu}$ exposure highly elevates fish intestinal $\mathrm{Cu} \operatorname{load}^{(17)}$. In grass carp, accumulation of $\mathrm{Cu}$ in intestine is higher than that in gill $^{(19)}$. Our previous study demonstrated that $\mathrm{Cu}$ exposure could induce oxidative stress in intestine and the enterocytes of juvenile Jian carp Cyprinus carpio var. Jian ${ }^{(16)}$. However, few studies examined how to efficiently protect the intestine against $\mathrm{Cu}$-induced oxidative damage. Given the increasing release of $\mathrm{Cu}$ into the environment and its potentially harmful effects on fish, it is important to expand our knowledge of how to protect fish against $\mathrm{Cu}$ toxicity. Some nutrients could prevent $\mathrm{Cu}-$ induced oxidative damage and change antioxidant capacity in fish enterocytes ${ }^{(16)}$.

Piscine antioxidant capacity can be assessed by the content of non-enzymatic compounds (e.g. GSH) and activities of antioxidant enzymes including superoxide dismutase (SOD), CAT and glutathione peroxidase (GPx), glutathione S-transferase (GST) and $\mathrm{GR}^{(20)}$. These antioxidant compounds and enzymes have key roles in eliminating the reactive oxygen species (ROS) in fish ${ }^{(21-23)}$. ROS are generated during normal cellular function, but high doses and/or inadequate removal of ROS results in oxidative stress that may cause severe metabolic malfunctions and impair cell health status ${ }^{(24)}$. NF-E2-related nuclear factor $2(\mathrm{Nrf} 2)$ is an important transcription factor that can bind to the antioxidant responsive element (ARE) and induce transcription of antioxidant enzyme genes ${ }^{(25)}$. Kelch-like ECH-associated protein 1 (Keap1) was identified as an Nrf2-binding protein, which depresses Nrf2 translocation to the nucleus ${ }^{(26)}$. Our previous report showed that antioxidant enzyme activities were regulated by the $\mathrm{Nrf} 2$ and Keap1 signalling molecules in fish ${ }^{(27)}$. Chen et $a l .{ }^{(28)}$ reported that the up-regulation of $N r f 2$ expression could elevate the antioxidant gene (including SOD, CAT, GPX, GR and GST) expression levels in the mouse liver. However, to date, no study has addressed the effect of Glu on Nrf2 signalling pathway in fish. Our recent study showed that Glu could regulate $N r f 2$ and Keap1a gene expression, maybe mediating the signal transduction involved in increased gene expressions of antioxidant enzymes in fish enterocytes $^{(6)}$.

The present study was designed to investigate whether Glu could attenuate $\mathrm{Cu}$-induced cellular oxidative damage, mediating through Nrf2 signalling pathways regulating mRNA expressions of antioxidant enzymes genes and synthesis of GSH in fish intestine.

\section{Methods}

In vivo experiments

Animal collection and acclimation conditions. Animal Care advisory Committee of Sichuan Agricultural University specifically approved this study. Yong grass carp were obtained from Tong Wei fisheries and acclimated for 4 weeks. Dissolved $\mathrm{O}_{2}$ was not $<6.0 \mathrm{mg} / \mathrm{l}$. Water temperature and $\mathrm{pH}$ were $24(\operatorname{sem} 3)^{\circ} \mathrm{C}$ and 7.5 (SEM 0.5$)$, respectively.

Protective effect of glutamate in copper-induced oxidative stress in the intestine. The formulations of the basal and experimental diets (Table 1) were similar as in our previous study $^{(5)}$. In brief, it contained $280 \mathrm{~g}$ of crude protein $/ \mathrm{kg}$ diet. The basal diet was Glu unsupplemented control (Ctrl). Glu was added to the basal diet to provide $8 \mathrm{~g} \mathrm{Glu} / \mathrm{kg}$ diet, which was the required Glu concentration for optimal growth established by our previous study ${ }^{(5)}$. Procedures for diet preparation and storage were the same as those described by Shiau \& Su${ }^{(29)}$. A total of 180 fish with an average initial weight of 247 (SEM 7.5) g from the acclimatisation tank were randomly assigned into two groups of three replicates each. The groups were fed either the Ctrl diet or the Glu diet for $56 \mathrm{~d}$. The experimental conditions were the same as in our previous study ${ }^{(5)}$.

At the end of the feeding trial, the fish in each tank were weighed and collected for $\mathrm{Cu}$ exposure. Fish with a similar body weight from both the Ctrl and Glu groups were exposed to $0.7 \mathrm{mg} \mathrm{Cu} / \mathrm{l}$ water for $96 \mathrm{~h}$, which has been proved to induce oxidative stress in grass carp according to our previous study ${ }^{(30)}$.

Table 1. Feed formulation and chemical composition of diets

\begin{tabular}{|c|c|c|c|c|c|}
\hline Diets & Ctrl group & Glu group & \multicolumn{2}{|c|}{ Ctrl group } & Glu group \\
\hline Formulation ( $\mathrm{g} / \mathrm{kg}$ diet) & & & \multicolumn{3}{|c|}{ Essential amino acids } \\
\hline Soyabean meal & 200 & 200 & Lys & $7 \cdot 2$ & $7 \cdot 2$ \\
\hline Rapeseed meal & 220 & 220 & Met & $2 \cdot 7$ & $2 \cdot 7$ \\
\hline Cotton meal & 92 & 92 & Thr & 9.7 & 9.8 \\
\hline Wheat flour & 424 & 416 & Arg & $9 \cdot 2$ & $9 \cdot 3$ \\
\hline Soya oil & 10 & 10 & Leu & $15 \cdot 4$ & $16 \cdot 1$ \\
\hline Monocalcium phosphate & 18 & 18 & His & 4.8 & 5.0 \\
\hline Choline chloride & 6 & 6 & Ile & $8 \cdot 2$ & $8 \cdot 8$ \\
\hline Vitamin premix ${ }^{*}$ & 10 & 10 & Phe & 8.4 & $9 \cdot 2$ \\
\hline Mineral premix $\dagger$ & 20 & 20 & Val & $11 \cdot 8$ & $11 \cdot 6$ \\
\hline L-Glu & 0 & 8 & \multicolumn{3}{|c|}{$\begin{array}{c}\text { Non-essential amino } \\
\text { acid }\end{array}$} \\
\hline \multirow[t]{2}{*}{ Total } & 1000 & 1000 & Ala & 14.9 & $15 \cdot 3$ \\
\hline & & & Asp & $15 \cdot 2$ & $15 \cdot 8$ \\
\hline $\begin{array}{l}\text { Analysed chemical } \\
\text { composition (g/kg DM) }\end{array}$ & & & Glu & 40.5 & 47.4 \\
\hline Proximate nutrients & & & Gly & 18.5 & $18 \cdot 3$ \\
\hline Crude protein & 266 & 277 & Pro & 13.4 & 13.5 \\
\hline Crude lipid & 37.5 & $37 \cdot 2$ & Ser & $12 \cdot 5$ & $12 \cdot 3$ \\
\hline Crude ash & 73.1 & 74.4 & Tyr & 5.5 & 5.9 \\
\hline
\end{tabular}

*Vitamin premix $(\mathrm{g} / \mathrm{kg})$ : retinyl acetate $(150 \mathrm{~g} / \mathrm{kg}), 0.80 \mathrm{~g}$; cholecalciferol $(12.5 \mathrm{~g} / \mathrm{kg}), 0.48 \mathrm{~g}$; DL- $\alpha$-tocopheryl acetate $(500 \mathrm{~g} / \mathrm{kg}), 2000 \mathrm{~g}$; menadione $(230 \mathrm{~g} /$ $\mathrm{kg}), 0.22 \mathrm{~g}$; thiamine hydrochloride $(980 \mathrm{~g} / \mathrm{kg}), 0.12 \mathrm{~g}$; riboflavin $(800 \mathrm{~g} / \mathrm{kg}), 0.99 \mathrm{~g}$; pyridoxine hydrochloride $(980 \mathrm{~g} / \mathrm{kg}), 0.62 \mathrm{~g}$; cyanocobalamin $(10 \mathrm{~g} / \mathrm{kg}), 0.10 \mathrm{~g}$; niacin $(990 \mathrm{~g} / \mathrm{kg}), 2.58 \mathrm{~g}$; D-biotin $(20 \mathrm{~g} / \mathrm{kg}), 5.00 \mathrm{~g}$; meso-inositol $(990 \mathrm{~g} / \mathrm{kg})$, $52.33 \mathrm{~g}$; folic acid $(960 \mathrm{~g} / \mathrm{kg}), 0.52 \mathrm{~g}$; ascorbyl acetate $(930 \mathrm{~g} / \mathrm{kg}), 7.16 \mathrm{~g}$; calciumD-pantothenate $(900 \mathrm{~g} / \mathrm{kg}), 2.78 \mathrm{~g}$. All ingredients were diluted with maize starch to $1 \mathrm{~kg}$.

† Mineral premix (g/kg): $\mathrm{FeSO}_{4} \cdot \mathrm{H}_{2} \mathrm{O}, 25.00 \mathrm{~g} ; \mathrm{CuSO}_{4} \cdot 5 \mathrm{H}_{2} \mathrm{O}, 0.60 \mathrm{~g} ; \mathrm{ZnSO}_{4} \cdot \mathrm{H}_{2} \mathrm{O}$, $4.35 \mathrm{~g} ; \mathrm{MnSO}_{4} \cdot \mathrm{H}_{2} \mathrm{O}, 2.04 \mathrm{~g} ; \mathrm{KI}, 1.10 \mathrm{~g} ; \mathrm{NaSeO}_{3}, 2.50 \mathrm{~g} ; \mathrm{MgSO}_{4} \cdot \mathrm{H}_{2} \mathrm{O}, 230.67 \mathrm{~g}$. All ingredients were diluted with $\mathrm{CaCO}_{3}$ to $1 \mathrm{~kg}$. 


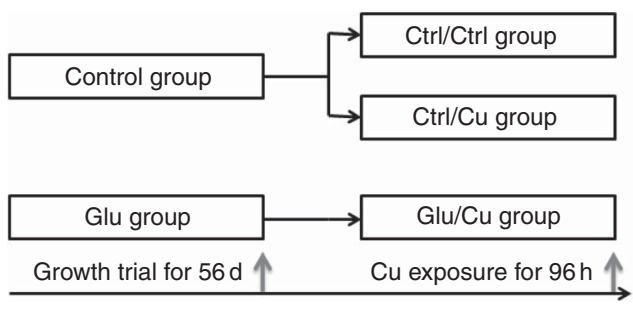

Fig. 1. Overview of experiment design in vivo.

In addition, the Ctrl/Ctrl treatment (fish from the Ctrl) was performed by exposing the fish from the Glu unsupplemented group to Cu-free water. Therefore, there were three different pre-treatment/exposure groups, $\mathrm{Ctrl} / \mathrm{Ctrl}, \mathrm{Ctrl} / \mathrm{Cu}$ and $\mathrm{Glu} / \mathrm{Cu}$, with three replicates per group and twelve fish per replicate (thirty-six fish for each group) (Fig. 1). During the $\mathrm{Cu}$ exposure period in replicates, the experimental conditions were the same as those in the growth trial, but no food was provided and the water was not renewed $^{(16)}$. At the end of the challenge trial, all of the living fish from each tank were anaesthetised in a benzocaine bath according to Basic et $a l^{(31)}$. The intestines of fish were quickly removed, frozen in liquid $\mathrm{N}_{2}$ and stored at $-80^{\circ} \mathrm{C}$ for further analysis. Because the fish were fasted for $96 \mathrm{~h}$ during $\mathrm{Cu}$ exposure, it was not necessary to empty the intestinal lumen ${ }^{(32)}$.

\section{In vitro experiments}

Chemicals. Copper sulphate pentahydrate $\left(\mathrm{CuSO}_{4} \cdot 5 \mathrm{H}_{2} \mathrm{O}\right)$, Glu, insulin, collagenase, dispase, D-sorbitol, Triton X-100, transferrin, benzyl penicillin and streptomycin sulphate were purchased from Sigma. Dulbecco's Modified Eagle's Medium (DMEM), Hank's balanced salt solution (HBSS) and fetal bovine serum (FBS) were purchased from Hyclone. Glu-free DMEM was ordered from Beijing Tsing Skywing Bio Tech Co. Ltd. 3-(4, 5-dimethylthiazol-2-yl)-5-(3-carboxymethoxyphenyl)2-(4-sulfophenyl)-2H-tetrazolium (MTS) was purchased from Promega Corporation.

Primary enterocyte culture. The isolation and culture of primary enterocytes from grass carp $C$. idella intestine were performed according to the methods of Jiang et al. ${ }^{(22)}$ with minor modifications. In brief, healthy grass carp with an average weight of 48.5 (SEM 1.2) g were food deprived for $24 \mathrm{~h}$ before the experiment and killed by decapitation. The intestines were rapidly separated from the carcass, opened and rinsed with HBSS containing antibiotics $(100 \mathrm{U} / \mathrm{ml}$ penicillin and $100 \mu \mathrm{g} / \mathrm{ml}$ streptomycin). Enterocytes were isolated by collagenase and dispase digestion. Next, cells were suspended in DMEM (containing 2\% D-Sorbitol, S-DMEM) and washed with S-DMEM five times to remove any undigested material and single cells according to Booth \& O'Shea ${ }^{(33)}$ with slight modifications. Isolated enterocytes were seeded in twenty-four-well culture plates (Falcon) at the density of $2 \times 10^{3}$ cells per well that had been previously coated with collagen I (Sigma), as previously described by us ${ }^{(34)}$. The cells were cultured in DMEM supplemented with 5\% FBS, $0.02 \mathrm{mg}$ transferrin $/ \mathrm{ml}$, $0.01 \mathrm{mg}$ insulin $/ \mathrm{ml}$ and antibiotics $(100 \mathrm{U} / \mathrm{ml}$ penicillin and $100 \mu \mathrm{g} / \mathrm{ml}$ streptomycin) at $26(\operatorname{sem~} 0 \cdot 5)^{\circ} \mathrm{C}$ under a Biochemical
Incubator (Shanghai Boxun Industry \& Commerce Co. Ltd) in an air atmosphere. The cells were allowed to attach to plates for $72 \mathrm{~h}$.

Prevention of copper-induced oxidative stress by glutamate in fish enterocytes. To investigate the effect of Glu on Cu-induced oxidative stress in fish enterocytes, cells were pre-treated with different concentrations of Glu $(0-12 \mathrm{mmol} / \mathrm{l})$ for $72 \mathrm{~h}$. Next, cells were exposed to $6 \mathrm{mg} \mathrm{Cu} / \mathrm{l} \mathrm{Glu}$-free medium for $24 \mathrm{~h}$ in a $27^{\circ} \mathrm{C}$ incubator. The $\mathrm{Cu}$ exposure concentration was chosen because previous experiments showed that $6 \mathrm{mg} / \mathrm{l} \mathrm{Cu}$ of medium could induce oxidative stress in carp enterocytes $^{(16)}$. Thus, there were eight groups (pre-treatment/ $\mathrm{Cu}$ exposure): $\mathrm{Ctrl} / \mathrm{Ctrl}$, Ctrl/Cu, 2mmol/1 Glu/Cu, 4mmol/1 Glu/ $\mathrm{Cu}, 6 \mathrm{mmol} / \mathrm{l} \mathrm{Glu} / \mathrm{Cu}, 8 \mathrm{mmol} / \mathrm{l} \mathrm{Glu} / \mathrm{Cu}, 10 \mathrm{mmol} / \mathrm{l} \mathrm{Glu} / \mathrm{Cu}$ and $12 \mathrm{mmol} / \mathrm{l} \mathrm{Glu} / \mathrm{Cu}$. At the end of the exposure, the MTS assay was performed. Cytotoxicity was determined by measuring lactate dehydrogenase (LDH) activity and malondialdehyde (MDA) in the culture media supernatants. Cell lysates were collected to detect protein carbonyl (PC) and GSH contents, alkaline phosphatase (AKP), ASA, AHR, SOD, CAT, GPx, GST and GR activities, and CAT, GPX, GST, GR, Nrf2 and Keap1a mRNA expression.

\section{Analysis and measurement}

Cell viability and differentiation assays. Cell viability in vivo experiments were quantified using the CellTiter $96{ }^{\circledR}$ AQueous One Solution cell proliferation assay kit (Promega). In brief, at the end of the experiment, $40 \mu \mathrm{l}$ of MTS working solution was added to each well. After incubation for $2 \mathrm{~h}$, the amount of formazan was determined by measuring the optical density (OD) at $490 \mathrm{~nm}$ on a plate reader (Wellscan MK3; Labsystems). AKP activity was assayed according to Krogdahl et al. ${ }^{(35)}$.

Lactate dehydrogenase, malondialdehyde, protein carbonyl and antioxidant parameter analysis. Cu-induced cytotoxicity was quantified by measuring the amounts of LDH released into the culture medium from injured cell in vitro experiments ${ }^{(36,37)}$. The amount of LDH released was measured using the method of Mulier et $a l^{(38)}$. MDA content was analysed as described by Zhang et $a l .{ }^{(39)}$ using the thiobarbituric acid reaction. The content of PC was determined according to the method described by Armenteros et $a l .{ }^{(40)}$ using 2, 4-dinitrophenylhydrazine reagent. The activities of SOD, CAT and GPx were determined by the method described by Chen et al. ${ }^{(28)}$. GST and GR activities were measured by the method described by Pandey et al. ${ }^{(41)}$ with minor modification. GSH contents were determined by using a method described by Chen et al. ${ }^{(23)}$ with a minor modification. The method is based on the formation of yellow colour when dithio nitrobenzoic acid reacts with compounds containing sulfhydryl groups. The amount of GSH was expressed as nmol of GSH per mg protein. ASA (anti-superoxide anion) and AHR (anti-hydroxy radical) activities were assayed according to the method described by Jiang et al. ${ }^{(42)}$.

ASA was determined using the Superoxide Anion Free Radical Detection Kit (Nanjing Jiancheng Bioengineer Institute). 
Superoxide anion $\left(\mathrm{O}_{2}^{-}\right.$. were generated by the action of xanthine and xanthine oxidase. When the electron acceptor added, a coloration reaction is developed using the nitro blue tetrazolium. The coloration degree is directly proportional to the quantity of superoxide anion in the reaction. If the sample has anti-superoxide anion activity, the superoxide anion in the reaction will decrease, so the coloration will be weak; if the sample can promote the production of superoxide anion, the coloration will be strong. The superoxide anion can be measured by colorimetry, and then ASA of the homogenate was calculated by the following formula: ASA $(\mathrm{U} / \mathrm{mg}$ protein $)=\left(\mathrm{OD}_{\text {control }}-\right.$ $\left.\mathrm{OD}_{\text {sample }}\right) /\left(\mathrm{OD}_{\text {standard }}-\mathrm{OD}_{\text {blank }}\right) \times$ standard $V_{C}$ concentration $(\mathrm{mmol} / \mathrm{l}) /$ protein contain $(\mathrm{mg})$. One unit is $1 \mathrm{mg}$ of homogenate scavenged superoxide anion free radical, which equals $1 \mathrm{mg}$ vitamin $\mathrm{C}$ scavenging in $40 \mathrm{~min}$ at $37^{\circ} \mathrm{C}$.

AHR was determined using the Hydroxyl Radical Detection Kit (Nanjing Jiancheng Bioengineer Institute). It was on the basis of Fenton reaction $\left(\mathrm{Fe}^{2+}+\mathrm{H}_{2} \mathrm{O}_{2} \rightarrow \mathrm{Fe}^{3+}+\mathrm{OH}^{-}+\cdot \mathrm{OH}\right)$. According to the principle, hydroxyl radicals are generated by Fenton reaction. When the electron acceptor added, a coloration reaction is developed using the nitro blue tetrazolium. The coloration degree is directly proportional to the quantity of hydroxyl radicals in the reaction. If the sample has anti-hydroxy radical activity, the hydroxyl radicals in the reaction will decrease, so the coloration will be weak; if the sample can promote the production of hydroxyl radicals, the coloration will be strong. The hydroxyl radicals can be measured by colorimetry, and then AHR of the homogenate was calculated by the following formula: AHR $(\mathrm{U} / \mathrm{mg}$ protein $)=\left(\mathrm{OD}_{\text {Control }}-\right.$ $\left.\mathrm{OD}_{\text {Sample }}\right) /\left(\mathrm{OD}_{\text {standard }}-\mathrm{OD}_{\text {blank }}\right) \times$ standard $\mathrm{H}_{2} \mathrm{O}_{2}$ concentration $(\mathrm{mmol} / \mathrm{l}) /$ protein contain $(\mathrm{mg})$. One unit is $1 \mathrm{mg}$ homogenate decreased $1 \mathrm{mmol} / 1 \mathrm{H}_{2} \mathrm{O}_{2}$ in $1 \mathrm{~min}$ at $37^{\circ} \mathrm{C}$. The protein contents were measured using the method of Bradford with bovine serum albumin standards ${ }^{(43)}$.

Real-time quantitative PCR. Total RNA was isolated using TRIZOL reagent (Invitrogen) according to the manufacturer's instructions. The RNA purity of each sample was determined by calculating the 260:280 ratio. The RNA integrity was assessed by inspection of the $28 \mathrm{~S}$ and $18 \mathrm{~S}$ ribosomal RNA bands in a $1 \%$ agarose gel. Subsequently, the $2 \mu$ lotal RNA was used to synthesise complementary DNA (cDNA) using the PrimeScript ${ }^{\circledR}$ RT reagent Kit with gDNA Eraser (Takara Biotechnology Co. Ltd). Real-time quantitative PCR analysis of CAT, GPX, GST, GR and house-keeping gene ( $\beta$-actin) was performed in a CFX96 Real-Time PCR Detection System (Bio-Rad). The gene-specific primers used in this study were listed in Table 2. The PCR mixture consisted of $1 \mu$ l of the first-strand cDNA sample, $0.5 \mu \mathrm{l}$ each of forward and reverse primers from $10 \mu \mathrm{m}$ stocks, $3 \mu \mathrm{l}$ of RNase-free $\mathrm{dH}_{2} \mathrm{O}$ and $5 \mu \mathrm{l}$ of $2 \times$ Ssofast EvaGreen Supermix (Bio-Rad). Cycling conditions were $98^{\circ} \mathrm{C}$ for $10 \mathrm{~s}$, followed forty cycles of $98^{\circ} \mathrm{C}$ for $5 \mathrm{~s}$, annealing at a different temperature (Table 2) for each gene for $10 \mathrm{~s}$ and $72^{\circ} \mathrm{C}$ for $15 \mathrm{~s}$. Target gene mRNA levels were normalised to the mRNA levels of the reference gene $\beta$-actin. The amount of the target gene was based on the threshold cycle number $(C T)$, and the $C T$ for each sample was determined using the CFX Manager ${ }^{\mathrm{TM}}$ software. All of the primer amplification efficiencies were approximately $100 \%$. The gene expression results were analysed using the $2^{-\triangle \Delta C T}$ method according to Jiang et al. ${ }^{(44)}$.

\section{Statistical analysis}

A $t$ test was used for comparisons between two groups in the growth trial. The other data were analysed by one-way ANOVA using SPSS 13.0 (SPSS Inc.). Duncan's multiple-range test was used to determine significant differences. Data are presented as means with their standard errors. $P<0.05$ was considered to be statistically significant.

\section{Results}

Glutamate prevented copper-induced oxidative damage of the intestine in vivo

Dietary supplementation with Glu significantly increased the growth of grass carp when compared with the Ctrl group - final weight: 614 (SEM 12.2) v. 560 (SEM 5.6) g (P<0.05). The effects of Glu on MDA, PC, SOD, CAT, GPx, GST, GR, ASA, AHR and GSH contents in intestine of grass carp under $\mathrm{Cu}$ exposure are

Table 2. The primers and annealing temperatures used in real-time quantitative PCR

\begin{tabular}{|c|c|c|c|}
\hline Names & Sequence $\left(5^{\prime}-3^{\prime}\right)$ & $\begin{array}{c}\text { Annealing } \\
\text { temperature }\left({ }^{\circ} \mathrm{C}\right)\end{array}$ & GenBank ID \\
\hline$C A T$ & $\begin{array}{l}\text { QF-GAAGTTCTACACCGATGAGG } \\
\text { QR-CCAGAAATCCCAAACCAT }\end{array}$ & 58.7 & FJ560431 \\
\hline$G R$ & $\begin{array}{l}\text { QF-GTGTCCAACTTCTCCTGTG } \\
\text { QR-ACTCTGGGGTCCAAAACG }\end{array}$ & $59 \cdot 4$ & JX854448 \\
\hline$G P x$ & $\begin{array}{l}\text { QF-GGGCTGGTTATTCTGGGC } \\
\text { QR-AGGCGATGTCATTCCTGTTC }\end{array}$ & 61.5 & EU828796 \\
\hline GST & $\begin{array}{l}\text { QF-TCTCAAGGAACCCGTCTG } \\
\text { QR-CCAAGTATCCGTCCCACA }\end{array}$ & 58.4 & EU107283 \\
\hline Nif2 & $\begin{array}{l}\text { QF-CTGGACGAGGAGACTGGA } \\
\text { QR-ATCTGTGGTAGGTGGAAC }\end{array}$ & $62 \cdot 5$ & KF733814 \\
\hline Keap1a & $\begin{array}{l}\text { QF-TTCCACGCCCTCCTCAA } \\
\text { QR-TGTACCCTCCCGCTATG }\end{array}$ & 63.0 & KF811013 \\
\hline$\beta$-Actin & $\begin{array}{l}\text { QF-GGCTGTGCTGTCCCTGTA } \\
\text { QR-GGGCATAACCCTCGTAGAT }\end{array}$ & 61.4 & M25013 \\
\hline
\end{tabular}

$C A T$, catalase; GR, glutathione reductase; GPX, glutathione peroxidase; GST, glutathione S-transferase; Nrf2, NF-E2-related nuclear factor 2; Keap1, Kelch-like ECH-associated protein 1. 
Table 3. Malondialdehyde (MDA), protein carbonyl (PC) and GSH contents (nmol/mg protein), anti-superoxide anion (ASA), anti-hydroxy radical (AHR), superoxide dismutase (SOD), catalase (CAT), glutathione peroxidase (GPX), glutathione S-transferase (GST), glutathione reductase (GR) activities $(\mathrm{U} / \mathrm{mg}$ protein) in the intestine of grass carp-fed diets containing different glutamate levels for $56 \mathrm{~d}$, followed by exposure to $0.7 \mathrm{mg} / \mathrm{l} \mathrm{Cu}$ for $96 \mathrm{~h}$ (Mean values with their standard errors, $n 6$ )

\begin{tabular}{|c|c|c|c|c|c|c|c|c|c|c|c|c|c|c|c|c|c|c|c|c|}
\hline \multirow[b]{2}{*}{ Groups } & \multicolumn{2}{|c|}{ MDA } & \multicolumn{2}{|c|}{ PC } & \multicolumn{2}{|c|}{ ASA } & \multicolumn{2}{|c|}{ AHR } & \multicolumn{2}{|c|}{ SOD } & \multicolumn{2}{|c|}{ CAT } & \multicolumn{2}{|c|}{ GPx } & \multicolumn{2}{|c|}{ GST } & \multicolumn{2}{|c|}{ GR } & \multicolumn{2}{|c|}{ GSH } \\
\hline & Mean & SEM & Mean & SEM & ean & SEM & Mean & SEM & lean & SEM & Mean & SEM & Mean & SEM & Mean & SEM & lean & SEM & lean & SEM \\
\hline trl & $1.50^{\mathrm{a}}$ & 0.08 & $2 \cdot 76^{a}$ & 0.14 & $358^{c}$ & 13.4 & $531^{c}$ & 11.7 & $62.5^{\mathrm{c}}$ & 2.9 & $50 \cdot 7^{\mathrm{a}}$ & 3.3 & $93 \cdot 6^{\mathrm{c}}$ & 4.6 & $191^{b}$ & $15 \cdot 1$ & $108^{b}$ & 11.5 & $13 \cdot 2^{c}$ & 1.4 \\
\hline $\mathrm{Ctrl} / \mathrm{Cu}$ & $2.59^{\mathrm{C}}$ & 0.12 & $3 \cdot 72^{b}$ & 0.18 & $261^{a}$ & 13.0 & $310^{\mathrm{a}}$ & $15 \cdot 2$ & $41 \cdot 8^{\mathrm{a}}$ & 4.0 & $67.0^{\mathrm{b}}$ & 2.7 & $58 \cdot 9^{a}$ & 5.5 & $143^{\mathrm{a}}$ & $6 \cdot 1$ & $65 \cdot 7^{\mathrm{a}}$ & 4.7 & $5 \cdot 52^{a}$ & 0.61 \\
\hline $8 \mathrm{~g} / \mathrm{kg} \mathrm{Glu} / \mathrm{Cu}$ & $1.65^{\mathrm{b}}$ & 0.14 & $2 \cdot 82^{\mathrm{a}}$ & 0.13 & $319^{b}$ & $16 \cdot 4$ & $406^{\mathrm{b}}$ & 13.7 & $56 \cdot 4^{\mathrm{b}}$ & 3.0 & $54 \cdot 1^{\mathrm{a}}$ & $4 \cdot 1$ & $78 \cdot 7^{\mathrm{b}}$ & $6 \cdot 3$ & $189^{b}$ & 9.2 & $112^{\mathrm{b}}$ & $10 \cdot 8$ & $11 \cdot 1^{\mathrm{b}}$ & $1 \cdot 1$ \\
\hline
\end{tabular}

a,b,c Mean values within a column with unlike superscript letters were significantly different $(P<0.05)$.

Table 4. Effect of different concentrations of glutamate on lactate dehydrogenase (LDH) activity and malondialdehyde (MDA) content in media, 3-(4, 5-dimethylthiazol-2-yl)-5-(3-carboxymethoxyphenyl)-2-(4-sulfophenyl)-2H-tetrazolium optical density (MTS OD), alkaline phosphatase (AKP) activities and protein carbonyl (PC) content in copper-exposed grass carp enterocytes* (Mean values with their standard errors, $n 6$ )

\begin{tabular}{|c|c|c|c|c|c|c|c|c|c|c|}
\hline \multirow[b]{2}{*}{ Groups } & \multicolumn{2}{|c|}{ MTS OD } & \multicolumn{2}{|c|}{ AKP (U/g protein) } & \multicolumn{2}{|c|}{ LDH (U/g protein) } & \multicolumn{2}{|c|}{ MDA (nmol/ml) } & \multicolumn{2}{|c|}{$\mathrm{PC}$ (nmol/mg protein) } \\
\hline & Mean & SEM & Mean & SEM & Mean & SEM & Mean & SEM & Mean & SEM \\
\hline Ctrl/Ctrl & $0.189^{d}$ & 0.005 & $2.09^{c}$ & 0.17 & $37.0^{\mathrm{b}}$ & $2 \cdot 8$ & $1.53^{\mathrm{a}}$ & 0.12 & $0.27^{\mathrm{a}}$ & 0.01 \\
\hline $\mathrm{Ctrl} / \mathrm{Cu}$ & $0 \cdot 157^{\mathrm{a}}$ & 0.009 & $1 \cdot 71^{\mathrm{a}}$ & 0.09 & $47 \cdot 3^{\mathrm{d}}$ & $2 \cdot 3$ & $2 \cdot 86^{d}$ & 0.23 & $0.40^{d}$ & 0.02 \\
\hline $2 \mathrm{mmol} / / \mathrm{Glu} / \mathrm{Cu}$ & $0.152^{\mathrm{a}, \mathrm{b}}$ & 0.005 & $1.88^{\mathrm{b}}$ & 0.10 & $43 \cdot 3^{c}$ & 1.9 & $2.78^{d}$ & 0.18 & $0.39^{d}$ & 0.02 \\
\hline $4 \mathrm{mmol} / \mathrm{l} \mathrm{Glu} / \mathrm{Cu}$ & $0 \cdot 160^{\mathrm{b}}$ & 0.006 & $1.97^{\mathrm{b}, \mathrm{c}}$ & 0.09 & $39 \cdot 5^{\mathrm{b}}$ & 1.4 & $2 \cdot 72^{d}$ & 0.08 & $0.36^{c}$ & 0.01 \\
\hline $6 \mathrm{mmol} / \mathrm{l} \mathrm{Glu} / \mathrm{Cu}$ & $0 \cdot 169^{c}$ & 0.005 & $2.03^{\mathrm{c}}$ & $0 \cdot 10$ & $37.0^{\mathrm{b}}$ & $1 \cdot 1$ & $2 \cdot 45^{\mathrm{c}}$ & $0 \cdot 10$ & $0.31^{b}$ & 0.02 \\
\hline $8 \mathrm{mmol} / / \mathrm{Glu} / \mathrm{Cu}$ & $0.173^{\mathrm{C}}$ & 0.008 & $2.04^{\mathrm{C}}$ & 0.09 & $31 \cdot 1^{\mathrm{a}}$ & $2 \cdot 4$ & $2 \cdot 31^{\mathrm{c}}$ & 0.10 & $0.29^{a, b}$ & 0.02 \\
\hline $10 \mathrm{mmol} / \mathrm{l} \mathrm{Glu} / \mathrm{Cu}$ & $0 \cdot 175^{\mathrm{c}}$ & 0.006 & $2.07^{c}$ & 0.16 & $29 \cdot 6^{\mathrm{a}}$ & 1.9 & $2 \cdot 13^{\mathrm{b}}$ & 0.07 & $0.29^{a, b}$ & 0.02 \\
\hline $12 \mathrm{mmol} / \mathrm{l} \mathrm{Glu} / \mathrm{Cu}$ & $0 \cdot 176^{c}$ & 0.007 & $2 \cdot 04^{c}$ & 0.13 & $32 \cdot 0^{\mathrm{a}}$ & 1.9 & $2 \cdot 15^{\mathrm{b}}$ & 0.09 & $0.28^{a}$ & 0.03 \\
\hline
\end{tabular}

a,b,c,d Mean values within a column with unlike superscript letters were significantly different $(P<0.05)$.

* The cells were pre-treated with different concentrations of Glu for $72 \mathrm{~h}$, followed by exposure to $6 \mathrm{mg} / \mathrm{l} \mathrm{Cu}$ for $24 \mathrm{~h}$.

displayed in Table 3. Compared with the Ctrl/Ctrl group, $\mathrm{Ctrl} / \mathrm{Cu}$ exposure caused a significant increase in MDA and PC content in the intestine $(P<0 \cdot 05)$. However, dietary Glu presupplementation $(\mathrm{Glu} / \mathrm{Cu})$ significantly decreased MDA and PC formation $(P<0.05)$. The activity of CAT in the intestine of grass carp was significantly increased by $\mathrm{Cu}$ exposure $(\mathrm{Ctrl} / \mathrm{Cu})$ $(P<0.05)$, whereas dietary Glu pre-supplementation $(\mathrm{Glu} / \mathrm{Cu})$ significantly prevented the increase in CAT activity $(P<0.05)$. In contrast, Ctrl/Cu exposure significantly decreased ASA, AHR, SOD, GPx, GST and GR activities in the intestine $(P<0.05)$. Glu pre-supplementation $(\mathrm{Glu} / \mathrm{Cu})$ significantly prevented the adverse effects of $\mathrm{Cu}$ on these enzyme activities $(P<0.05)$. The intestinal GSH content was the lowest in the $\mathrm{Ctrl} / \mathrm{Cu}$ treatment, followed by the Glu/Cu treatment, and the GSH content was the highest in the $\mathrm{Ctrl} / \mathrm{Ctrl}$ group $(P<0.05)$.

\section{Glutamate reduced copper-induced oxidative damage of enterocytes in vitro}

The present study has investigated the protective effects of Glu pre-treatment on $\mathrm{Cu}$-induced enterocyte oxidative stress. The $\mathrm{Cu}$ exposure $(\mathrm{Ctrl} / \mathrm{Cu})$ significantly increased $\mathrm{LDH}$ release, MDA content in the medium and PC content in enterocytes as compared with the unexposed Ctrl group ( $\mathrm{Ctrl} / \mathrm{Ctrl})(P<0.05)$ (Table 4). However, pre-treatment with $6-12 \mathrm{mmol} / \mathrm{l}$ before exposure to $\mathrm{Cu}$ significantly reduced $\mathrm{LDH}$ release, MDA generation and $\mathrm{PC}$ formation induced by $\mathrm{Cu}(P<0.05)$ (Table 4$)$. Exposure to $\mathrm{Cu}$ was shown to cause a significant decrease in
MTS OD values and AKP activity compared with that of the Ctrl $(P<0.05)$ (Table 4$)$. As expected, pre-treatment with Glu partially prevented the decrease in cell viability and AKP activity induced by $\mathrm{Cu}(P<0.05)$ (Table 4$)$. ASA and AHR activities of enterocytes are shown in Fig. 2. Cu exposure alone significantly decreased ASA and AHR activities in enterocytes. When cells were pre-treated with increasing doses of Glu, before Cu stress, ASA and AHR activities were increased in a dose-dependent manner $(P<0.05)$.

The effects of Glu on antioxidant parameters in enterocytes under $\mathrm{Cu}$ exposure are displayed in Table 5. The T-SOD, GST and GR activities and GSH content were significantly decreased in cells exposed to $\mathrm{Cu}$ as compared with the unexposed Ctrl treatment $(P<0 \cdot 05)$. However, pre-treatment with Glu partially prevented a marked reduction in T-SOD, GST and GR activities and GSH content induced by $\mathrm{Cu}(P<0 \cdot 05)$ (Table 5). In contrast, $\mathrm{Cu}$ exposure alone significantly increased the CAT and GPx activities. However, pre-treatment with Glu partially prevented the increase in CAT activity. Interestingly, cells pretreated with Glu further increased high GPx activity (Table 5).

Effects of glutamate on antioxidant-related and NF-E2related nuclear factor 2 signalling molecule gene expression in the intestine in vivo

As shown in Fig. 3, the $\mathrm{Ctrl} / \mathrm{Cu}$ treatment increased the relative mRNA expression levels of $C A T$ in the intestine of grass carp 


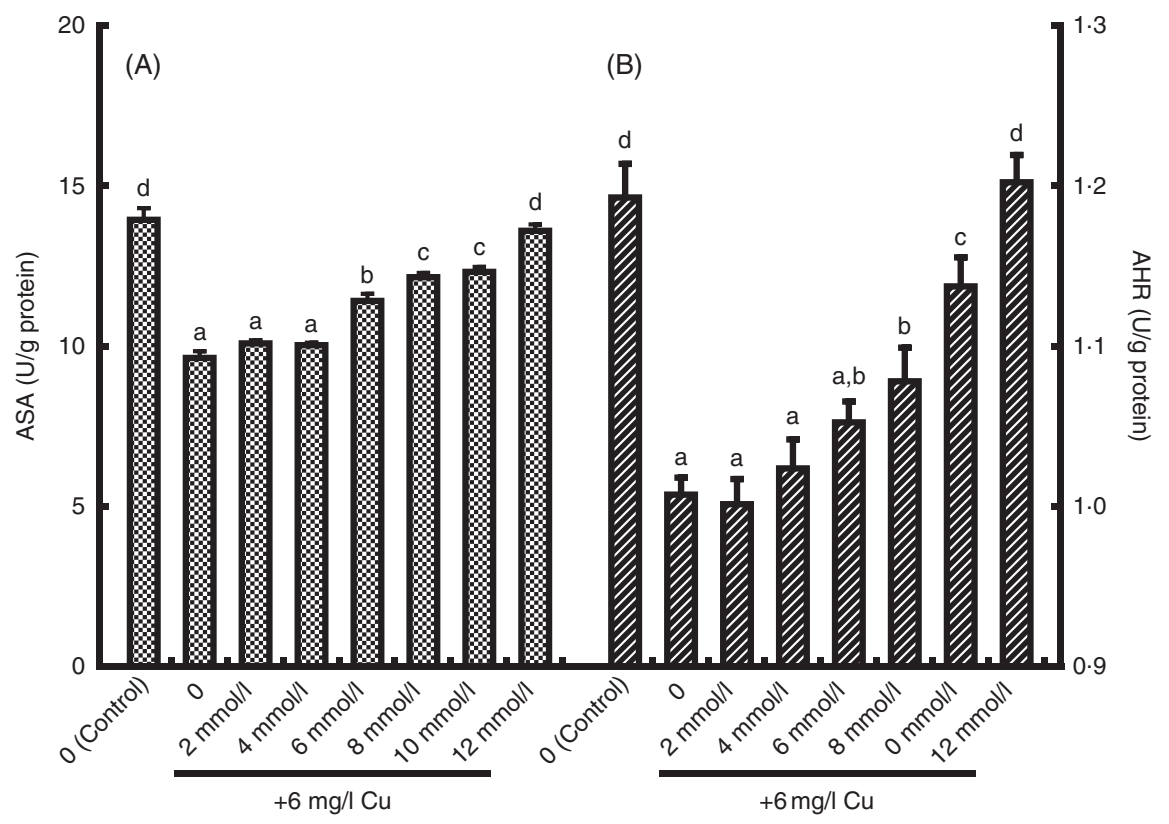

Fig. 2. The anti-superoxide anion (ASA, U/g protein) (A) and anti-hydroxyl radical (AHR, U/g protein), (B) activities in enterocytes cultured with medium containing graded levels of Glu for $72 \mathrm{~h}$, followed by exposure to $6 \mathrm{mg} / \mathrm{Cu}$ for $24 \mathrm{~h}$. Values are means of six replicates, with their standard errors. ${ }^{\mathrm{a}, \mathrm{b}, \mathrm{c}, \mathrm{d}}$ Mean values with unlike letters were significantly different $(P<0.05)$.

Table 5. Effect of different concentrations (U/mg protein) of glutamate on total superoxide dismutase (T-SOD), catalase (CAT), glutathione peroxidase (GPx), glutathione S-transferase (GST), glutathione reductase (GR) activities and GSH content (nmol/mg protein) in copper-exposed grass carp enterocytes*

(Mean values with their standard errors, $n 6$ )

\begin{tabular}{|c|c|c|c|c|c|c|c|c|c|c|c|c|}
\hline \multirow[b]{2}{*}{ Groups } & \multicolumn{2}{|c|}{ T-SOD } & \multicolumn{2}{|c|}{ CAT } & \multicolumn{2}{|c|}{ GPx } & \multicolumn{2}{|c|}{ GST } & \multicolumn{2}{|c|}{ GR } & \multicolumn{2}{|c|}{ GSH } \\
\hline & Mean & SEM & Mean & SEM & Mean & SEM & Mean & SEM & Mean & SEM & Mean & SEM \\
\hline $\mathrm{Ctr} / \mathrm{Ctrl}$ & $10 \cdot 9^{d}$ & 1.0 & $2.02^{a}$ & 0.12 & $492 \cdot 2$ & $13 \cdot 3^{a}$ & $161.6^{\mathrm{d}}$ & 11.6 & $22 \cdot 7^{\mathrm{e}}$ & 0.9 & $21 \cdot 3^{\mathrm{e}}$ & 0.5 \\
\hline $\mathrm{Ctr} / \mathrm{Cu}$ & $3.58^{\mathrm{a}}$ & 0.57 & $7 \cdot 11^{\mathrm{e}}$ & 0.20 & $571 \cdot 8^{\mathrm{b}}$ & $12 \cdot 3$ & $96 \cdot 6^{\mathrm{a}}$ & $10 \cdot 1$ & $13 \cdot 0^{a}$ & 1.0 & $14 \cdot 3^{\mathrm{a}}$ & 0.3 \\
\hline $2 \mathrm{mmol} / / \mathrm{Glu} / \mathrm{Cu}$ & $3.96^{\mathrm{a}}$ & 0.19 & $7 \cdot 01^{\mathrm{d}, \mathrm{e}}$ & 0.17 & $578 \cdot 3^{b}$ & 8.9 & $100 \cdot 9^{a}$ & $12 \cdot 7$ & $14 \cdot 0^{\mathrm{a}, \mathrm{b}}$ & 0.8 & $14 \cdot 2^{\mathrm{a}, \mathrm{b}}$ & 0.2 \\
\hline $4 \mathrm{mmol} / \mathrm{l} \mathrm{Glu} / \mathrm{Cu}$ & $4 \cdot 10^{a, b}$ & 0.20 & $6.76^{\mathrm{d}}$ & 0.16 & $582.5^{\mathrm{b}}$ & 13.5 & $110 \cdot 4^{a, b}$ & $10 \cdot 3$ & $14.5^{\mathrm{b}}$ & 0.9 & $15 \cdot 9^{b}$ & 0.4 \\
\hline $6 \mathrm{mmoll} \mathrm{Glu} / \mathrm{Cu}$ & $4.51^{b}$ & 0.20 & $6 \cdot 25^{c}$ & 0.28 & $616 \cdot 4^{c}$ & 11.6 & $117 \cdot 6^{\mathrm{b}}$ & 11.6 & $16 \cdot 1^{\mathrm{c}}$ & 0.8 & $16 \cdot 9^{c}$ & 0.3 \\
\hline $8 \mathrm{mmol} / \mathrm{l} \mathrm{Glu} / \mathrm{Cu}$ & $4.52^{\mathrm{b}}$ & 0.23 & $5 \cdot 40^{\mathrm{b}}$ & 0.18 & $645 \cdot 4^{\mathrm{d}}$ & 9.2 & $120 \cdot 5^{\mathrm{b}}$ & 7.8 & $17 \cdot 6^{\mathrm{d}}$ & 1.3 & $17.5^{\mathrm{d}}$ & 0.3 \\
\hline $10 \mathrm{mmol} / / \mathrm{Glu} / \mathrm{Cu}$ & $5 \cdot 21^{c}$ & 0.17 & $5 \cdot 26^{\mathrm{b}}$ & 0.26 & $666 \cdot 5^{\mathrm{e}}$ & 10.4 & $134.9^{c}$ & 13.1 & $15 \cdot 9^{c}$ & 1.0 & $16 \cdot 9^{\mathrm{C}}$ & 0.4 \\
\hline $12 \mathrm{mmol} / \mathrm{l} \mathrm{Glu} / \mathrm{Cu}$ & $5.42^{\mathrm{c}}$ & 0.13 & $5 \cdot 34^{b}$ & 0.42 & $670 \cdot 8^{e}$ & 29.5 & $162 \cdot 4^{d}$ & $12 \cdot 8$ & $18 \cdot 3^{d}$ & 1.0 & $18 \cdot 3^{\mathrm{d}}$ & 0.3 \\
\hline
\end{tabular}

a,b,c,d,e Mean values within a column with unlike superscript letters were significantly different $(P<0.05)$

* The cells were pre-treated with different concentrations $(0,2,4,6,8,10,12 \mathrm{mmol} / \mathrm{l})$ of Glu for $72 \mathrm{~h}$, followed by exposure to $6 \mathrm{mg} / \mathrm{l}$ of $\mathrm{Cu}$ for $24 \mathrm{~h}$.

compared with the Ctrl/Ctrl group $(P<0.05)$. Dietary Glu treatment $(\mathrm{Glu} / \mathrm{Cu})$ significantly prevented the up-regulation of CAT mRNA expression $(P<0 \cdot 05)$. The $\mathrm{Ctrl} / \mathrm{Cu}$ treatment caused a significant decrease in GR, GPX and GST mRNA expression in the intestine when compared with the $\mathrm{Ctrl} / \mathrm{Ctrl}(P<0 \cdot 05)$. Pretreatment with Glu prevented down-regulation of the $G R, G P x$ and GST mRNA expression $(P<0 \cdot 05)$. The effects of Glu on $N r f 2$ and Keap1a mRNA expression in the intestine of fish following $\mathrm{Cu}$ exposure are presented in Fig. 3. Fish exposed to $\mathrm{Cu}$ showed a decrease in $N r f 2$ mRNA expression of intestine as compared with the Ctrl/Ctrl group $(P<0.05)$, and Glu markedly inhibited down-regulation of Cu-induced $N r f 2$ mRNA expression $(P<0.05)$. Exposure to $\mathrm{Cu}$ significantly increased Keap1a transcript abundances in intestine of grass carp compared with the untreated control $(P<0.05)$. Pre-treatment with Glu decreased Keap1a mRNA expression $(P<0 \cdot 05)$.

\section{Effects of glutamate on antioxidant enzyme genes and} NF-E2-related nuclear factor 2 signalling molecule in vitro

Relative gene expressions of CAT, GPX, GST, GR, Nfr2 and Keap1a in enterocytes were presented in Fig. 4. Cu exposure alone significantly increased $C A T$ and GPX mRNA expression $(P<0.05)$. Pre-treatment with Glu resulted in a significant increase of levels of GPX mRNA as compared with the Cu stress treatment. However, GST and GR mRNA expression were significantly decreased by $\mathrm{Cu}$ stress alone, and Glu markedly inhibited Cu-induced down-regulation of GST and GR mRNA expression $(P<0.05)$. The relative expression level of $\mathrm{Nrf2}$ in enterocytes was significantly down-regulated by $\mathrm{Cu}$ stress alone $(P<0.05)$. Pre-treatment with $\mathrm{Glu}$ before $\mathrm{Cu}$ exposure significantly depressed $\mathrm{Cu}$-induced down-regulation of $\mathrm{Nrf} 2$ mRNA $(P<0.05)$. Cu exposure significantly increased the 
relative mRNA expression levels of Keap1a in enterocytes $(P<0.05)$. Pre-treatment of cells with Glu partially prevented the increase in Cu-induced relative mRNA expression of Keapla $(P<0 \cdot 05)$.

\section{Discussion}

$\mathrm{Cu}$ is an essential nutrient, which has numerous functions in cellular biochemistry (such as a cofactor for many different enzymes) ${ }^{(45)}$. However, $\mathrm{Cu}$ at higher concentrations may be toxic. The toxicity of $\mathrm{Cu}$ is suggested to be mainly caused by oxidative stress in fish ${ }^{(46)}$. It was demonstrated that $\mathrm{Cu}$ exposure could induce oxidative stress in zebrafish hepatocytes ${ }^{(14)}$, rainbow trout gill cell ${ }^{(46)}$ and carp enterocytes ${ }^{(16)}$. Oxidative damage in cultured cells has been assessed by LDH release ${ }^{(47)}$. The extent of cell damage was assessed by measuring the release of the cytosolic enzyme LDH from damaged cells to the bathing medium ${ }^{(48)}$. The present study demonstrated that $\mathrm{Cu}$

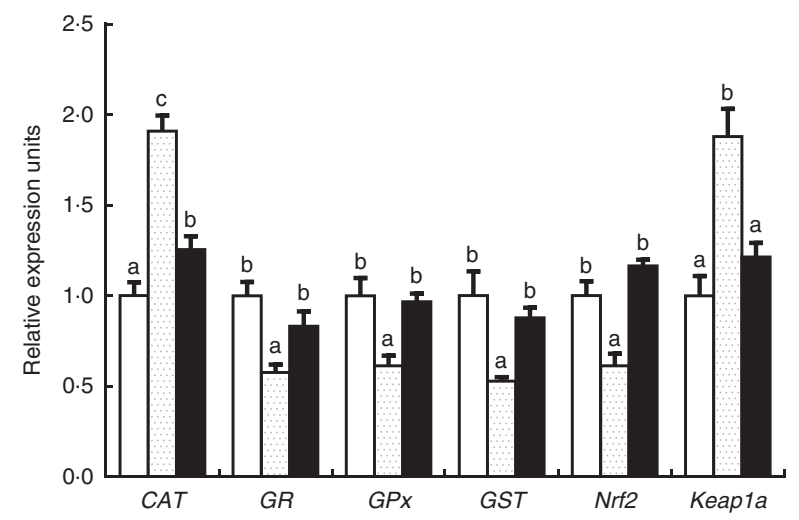

Fig. 3. Relative gene expression (shows to be relative to $\mathrm{Ctrl} / \mathrm{Ctrl}(\square)$, which was set at 1.0, in arbitrary units) of catalase $(C A T)$, glutathione reductase $(G R)$, glutathione peroxidase $(G P x)$, glutathione S-transferase (GST), NF-E2-related nuclear factor 2 (Nrf2) and Kelch-like ECH-associated protein 1 (Keap1) in the intestine of young grass carp (Ctenopharyngodon idella) fed diets containing different Glu levels for $56 \mathrm{~d}$, followed by exposure to $0.7 \mathrm{mg} / \mathrm{l} \mathrm{Cu}$ for $96 \mathrm{~h}$. Values are means of six replicates, with their standard errors. ${ }^{a, b, c}$ Mean values with unlike letters were significantly different $(P<0.05)$. $\square, \mathrm{Ctrl} / \mathrm{Cu} ; \square, \mathrm{Glu} / \mathrm{Cu}$. exposure significantly increased LDH levels in the medium, indicating severe enterocyte damage. The colorimetric assay using MTS can rapidly quantify the cell viability of fish enterocyte $^{(44,49)}$. AKP serves as an enterocyte differentiation marker and is considered to be involved in the absorption of nutrients ${ }^{(50)}$. In the present study, $\mathrm{Cu}$ exposure significantly decreased cell viability and AKP activity. Interestingly, treatment of Cu-exposed enterocytes with some concentrations of Glu depressed LDH release, and elevated cell viability and AKP activity. MDA and PC contents were widely used as biochemical indicators of oxidative damage ${ }^{(51)}$. Exposure of enterocytes to $6 \mathrm{mg} / \mathrm{l} \mathrm{Cu}$ was shown to cause a significant increase in MDA and $\mathrm{PC}$ contents, suggesting that $\mathrm{Cu}$ exposure caused lipid and protein oxidative damage in enterocytes, which may be attributed to the increase of ROS production. ROS are produced in response to metals ${ }^{(52)}$. Increasing the levels of ROS can lead to severe cell injury or death ${ }^{(53)}$. Superoxide anions can cause a wide range of oxidative damage within the cell ${ }^{(51)}$. The present study showed that MDA and PC contents were decreased in cells treated with Glu in a dose-dependent manner. The result suggested that Glu may exert potent protection of the intestine against $\mathrm{Cu}$-induced oxidative damage. To our knowledge, no study has investigated the protective effects of Glu against metal toxicity. This is the first report demonstrating that Glu could attenuate $\mathrm{Cu}$-induced cellular damage.

To investigate the potential protective effects of Glu against Cu-induced oxidative damage, the antioxidant enzymes such as SOD, CAT, GPx, GST, GR and GSH content were determined. The SOD is the first enzyme to respond against $\mathrm{O}_{2}$ radicals and important endogenous antioxidants for protection against oxidative stress ${ }^{(54)}$. CAT has been implicated as an essential defence against the potential toxicity of hydroxyl radicals ${ }^{(55)}$. The GSH-dependent enzymes (GST, GPx and GR) are able to counteract peroxidative damage ${ }^{(56)}$. GSH is the major endogenous antioxidant scavenger that protects cells from oxidative stress, and GSH/GSSG represents the major cellular redox buffer and therefore is a representative indicator for the redox environment of the cell ${ }^{(57)}$. In the present study, a significant decrease in SOD and GR activities and GSH content was found

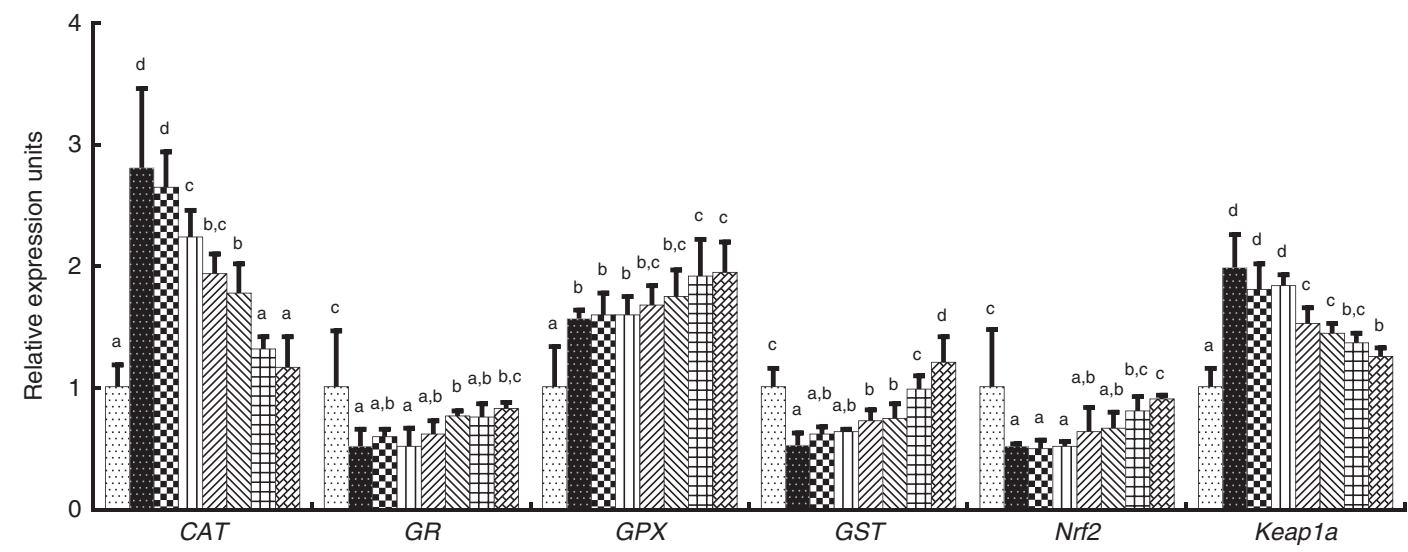

Fig. 4. Relative expression (shows to be relative to $\mathrm{Ctrl} / \mathrm{Ctrl}$, which was set at $1 \cdot 0$, in arbitrary units) of catalase (CAT), glutathione reductase (GR), glutathione peroxidase $(G P x)$, glutathione S-transferase (GST), NF-E2-related nuclear factor 2 (Nrf2) and Kelch-like ECH-associated protein 1 (Keap1) mRNA in enterocytes cultured with medium containing graded levels of Glu for $72 \mathrm{~h}$, followed by exposure to $6 \mathrm{mg} / \mathrm{l} \mathrm{Cu}$ for $24 \mathrm{~h}$. Values are means of six replicates, with their standard errors. a,b,c,d Mean values with

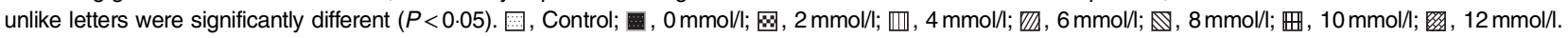


in cells exposed to $\mathrm{Cu}$. The result demonstrated that $\mathrm{Cu}$-induced enterocyte oxidative damage may be partly related to disturbance of the antioxidant system. Glu pre-treatment prevented a Cu-induced decrease of these antioxidant enzyme activities. This may suggest that the antioxidative effect of Glu may be attributed to its ability to maintain the activity of radical scavenging enzymes. A variety of citrate cycle intermediates such as fumarate, oxaloacetate, malate and succinate were shown to modulate lipid peroxide production by interacting with endogenous iron ions, thus adjusting the iron redox cycle and, subsequently, free-radical generation ${ }^{(58)}$. Glu can form $\alpha$-ketoglutarate by deamination and enter into the citrate cycle to promote the production of citrate cycle intermediates ${ }^{(3)}$. Hence, the reduction in lipid peroxides with an increase in GSH on Glu pre-treatment could be because of the antioxidant effect of citrate cycle intermediates formed from Glu. Further, GSH was produced from exogenous $\mathrm{Glu}^{(2)}$. However, $\mathrm{Cu}$ exposure significantly elevated CAT and GPx activities. Glu pre-treatment of enterocytes further increased GPx activities. The reason might be attributed to an adaptive mechanism against stress. The enterocytes were directly exposed to $\mathrm{Cu}$; increased CAT and GPx activities were required to inhibit the $\mathrm{Cu}$-induced oxidative stress. The ASA and AHR activity are two indexes used to evaluate the total capacity of scavenging superoxide and hydroxyl radical, respectively ${ }^{(22)}$. To investigate how Glu inhibited the $\mathrm{Cu}$-induced oxidative damage in fish, we determined the ASA and AHR activities. Our results showed that $\mathrm{Cu}$ exposure significantly decreased the ASA and AHR activities in enterocytes. Glu pre-treatment prevented the Cu-induced decrease of ASA and AHR activities in a dose-dependent manner. These results indicated that the protective effects of Glu on Cu-induced oxidative damage may, at least in part, be because of the increased ASA and AHR activities.

The activities of antioxidant enzymes can be affected by the mRNA levels in fish ${ }^{(27)}$. To further elucidate whether Glu regulated antioxidant enzyme activities at the gene level in fish, the mRNA levels of antioxidant enzyme of enterocytes after being challenged against $\mathrm{Cu}$ were investigated. The results of the current study demonstrated that $\mathrm{Cu}$ exposure significantly increased mRNA levels of CAT and GPX in enterocytes. Glu pre-treatment blocked the increase in CAT mRNA expression induced by $\mathrm{Cu}$. However, Glu pre-treatment further elevated mRNA expression of GPx gene induced by $\mathrm{Cu}$. The antioxidant enzyme gene expression exhibited a same pattern with their respective enzyme changes. The regulation of antioxidant gene mRNA levels may result from activating the antioxidant-related signalling molecules. Nrf2 is a master regulator of the antioxidant response through regulating the transcription of antioxidant gene in fish, including $S O D, C A T, G P x, G R$ and $G S T^{(26)}$. The present study showed that $\mathrm{Cu}$ exposure downregulated the $N r f 2$ gene expression in enterocytes. The result is very well in agreement with our previous report, which showed that $\mathrm{Cu}$ exposure markedly decreased the binding of nuclear $\mathrm{Nrf} 2$ to $\mathrm{ARE}^{(59)}$. In addition, the negative effects of $\mathrm{Cu}$-induced antioxidant gene mRNA expression may be partly ascribed to a decrease in Nrf2 nuclear translocation. Keap1 is identified as an Nrf2-binding protein that prevents Nrf2 translocation to the nucleus and promotes the ubiquitination-proteasomal degradation of $\mathrm{Nrf}^{(26)}$. Our study also showed that $\mathrm{Cu}$ induces the up-regulation of Keap1a mRNA level in enterocytes ${ }^{(6)}$. Glu pre-treatment elevated $N r f 2$ mRNA expression and blocked the increase in Keap1a mRNA expression ${ }^{(6)}$. These results suggested that the antioxidant effect of Glu is mediated at least in part by Nrf2 signalling pathways in fish. To date, no information is available about the effect of Glu on $N r f 2$ gene mRNA expression in fish enterocytes. The underlying mechanism needs further investigation.

On the basis of the beneficial effects of Glu against Cu-induced oxidative damage in the enterocytes, it was reasonable to hypothesise that Glu can protect fish against Cu-induced intestinal oxidative damage in vivo. The present study showed that $\mathrm{Cu}$ exposure could induce intestinal oxidative stress in grass carp. Similar results were observed that $\mathrm{Cu}$ exposure could induce oxidative stress in juvenile Epinephelus coioides intestine ${ }^{(60)}$ and pacu Piaractus mesopotamicus liver ${ }^{(61)}$. The antioxidant enzyme activities of intestine were elevated in response to Glu supplementation. The GR, GPX and GST mRNA abundance in intestine was enhanced by Glu pre-treatment. The positive effects of Glu on antioxidant enzyme mRNA expression may be partly ascribed to promote $\mathrm{Nrf} 2$ nuclear translocation by down-regulating Keap1a mRNA expression. In the present study, a significant increase in mRNA levels of $N r f 2$ was observed in the grass carp intestine with Glu supplementation. In contrast, Glu pre-treatment significantly decreased Keap1a mRNA expression. These results were in agreement with the present study statements in vitro. Studies from rats also indicated that Glu supplementation alleviates oxidative damage induced by isoproterenol ${ }^{(7)}$. However, it is of interest that the in vivo GPx activity in intestine was decreased by $\mathrm{Cu}$ exposure, which was the reverse of the pattern observed in enterocytes. The reason for these results is unclear. The differences may be because, in this study, the enterocytes were directly exposed to $\mathrm{Cu}$, whereas the intestine is indirectly exposed to $\mathrm{Cu}$. In other words, because the enterocytes were directly exposed to $\mathrm{Cu}$, increased GPx activity was required to inhibit the $\mathrm{Cu}$-induced oxidative stress. The previous study in grass carp showed that dietary $\mathrm{Cu}$ content $(5.25 \mathrm{mg} / \mathrm{kg})$, beyond requirement $(4.78 \mathrm{mg} / \mathrm{kg})$, induced intestinal oxidative stress, but increased GPx activity ${ }^{(9)}$. In addition, higher doses of $\mathrm{Cu}(6.70-8.33 \mathrm{mg} / \mathrm{kg})$ induced intestinal oxidative stress and decreased the GPx activity at the same time ${ }^{(9)}$. Therefore, the enterocytes directly exposed to a certain amount of $\mathrm{Cu}$ by culture in vitro and oral administration in vivo can both induce oxidative stress, as well as increase GPx activity in fish intestine.

In conclusion, $\mathrm{Cu}$ exposure could induce oxidative damage, resulting in lipid peroxidation, protein oxidation and antioxidant enzymes activity alterations in intestine and the enterocytes of grass carp. Cu exposure down-regulated the mRNA abundance of GR, GPx and GST in the intestine of grass carp. Dietary and medium pre-supplementation with Glu could alleviate Cu-induced oxidative damage in fish intestine and the enterocytes, respectively. The protective effects of Glu on $\mathrm{Cu}$-induced oxidative damage are associated with up-regulating the expression of antioxidant enzymes gene by regulating mRNA abundance of signalling molecule $N r f 2$. It provides a 
theoretical basis for reducing oxidative stress of $\mathrm{Cu}$ in cultured fish by means of nutrition.

\section{Acknowledgements}

The authors would like to express their sincere thanks to the personnel of these teams for their kind assistance.

This study was financially supported by the Youth Foundation Program of the Education Department of Sichuan Province, China (grant no. 14ZB0021) and the Applied Basic Research Programs of Science and Technology Commission Foundation of Sichuan Province, China (grant no. 2015JY0067).

J. J. and X.-Y. W. conducted the trial, performed the RT-PCR experiments and wrote the manuscript. Y. Z. and X.-Q. Z. contributed to the design of the study. L. F. and W.-D. J. assisted in the manuscript preparation. Y. L. assisted with all data analysis. P. W. assisted with the trail.

The authors declare that there are no conflicts of interest.

\section{References}

1. Rezaei R, Knabe DA, Tekwe CD, et al. (2013) Dietary supplementation with monosodium glutamate is safe and improves growth performance in postweaning pigs. Amino Acids 44, 911-923.

2. Reeds PJ, Burrin DG, Stoll B, et al. (2000) Intestinal glutamate metabolism. J Nutr 130, 978S-982S.

3. Blachier F, Boutry C, Bos C, et al. (2009) Metabolism and functions of L-glutamate in the epithelial cells of the small and large intestines. Am J Clin Nutr 90, 814S-821S.

4. Johnson AT, Kaufmann Y, Luo S, et al. (2003) Gut glutathione metabolism and changes with 7,12-DMBA and glutamine. J Surg Res 115, 242-246.

5. Zhao Y, Hu Y, Zhou XQ, et al. (2015) Effects of dietary glutamate supplementation on growth performance, digestive enzyme activities and antioxidant capacity in intestine of grass carp (Ctenopharyngodon idella). Aquacult Nutr 21, 935-941.

6. Jiang J, Shi D, Zhou X, et al. (2015) Effects of glutamate on growth, antioxidant capacity, and antioxidant-related signaling molecule expression in primary cultures of fish enterocytes. Fish Physiol Biochem 41, 1143-1153.

7. Sivakumar R, Babu PVA \& Srinivasulu Shyamaladevi C (2011) Aspartate and glutamate prevents isoproterenol-induced cardiac toxicity by alleviating oxidative stress in rats. Exp Toxicol Pathol 63, 137-142.

8. Puig S \& Thiele DJ (2002) Molecular mechanisms of copper uptake and distribution. Curr Opin Chem Biol 6, 171-180.

9. Tang QQ, Feng L, Jiang WD, et al. (2013) Effects of dietary copper on growth, digestive, and brush border enzyme activities and antioxidant defense of hepatopancreas and intestine for young grass carp (Ctenopharyngodon idella). Biol Trace Elem Res 155, 370-380.

10. Hall LW, Scott MC \& Killen WD (1998) Ecological risk assessment of copper and cadmium in surface waters of chesapeake bay watershed. Environ Toxicol Chem 17, 1172-1189.

11. James R, Sampath K, Jothilakshmi S, et al. (2008) Effects of copper toxicity on growth, reproduction and metal accumulation in chosen ornamental fishes. Ecohydrol Hydrobiol 8, 89-97.

12. Eyckmans M, Celis N, Horemans N, et al. (2011) Exposure to waterborne copper reveals differences in oxidative stress response in three freshwater fish species. Aquat Toxicol 103, $112-120$.
13. Wang T, Long X, Cheng Y, et al. (2014) The potential toxicity of copper nanoparticles and copper sulphate on juvenile Epinephelus coioides. Aquat Toxicol 152, 96-104.

14. Sandrini JZ, Bianchini A, Trindade GS, et al. (2009) Reactive oxygen species generation and expression of DNA repairrelated genes after copper exposure in zebrafish (Danio rerio) ZFL cells. Aquat Toxicol 95, 285-291.

15. Olsen RE, Sundell K, Mayhew TM, et al. (2005) Acute stress alters intestinal function of rainbow trout, Oncorbynchus mykiss (Walbaum). Aquaculture 250, 480-495.

16. Jiang W, Wu P, Kuang S, et al. (2011) Myo-inositol prevents copper-induced oxidative damage and changes in antioxidant capacity in various organs and the enterocytes of juvenile Jian carp (Cyprinus carpio var. Jian). Aquat Toxicol 105, 543-551.

17. Ransberry VE, Morash AJ, Blewett TA, et al. (2015) Oxidative stress and metabolic responses to copper in freshwater- and seawater-acclimated killifish, Fundulus beteroclitus. Aquat Toxicol 161, 242-252.

18. Al-Bairuty GA, Shaw BJ, Handy RD, et al. (2013) Histopathological effects of waterborne copper nanoparticles and copper sulphate on the organs of rainbow trout (Oncorbynchus mykiss). Aquat Toxicol 126, 104-115.

19. Liu F, Ni H, Chen F, et al. (2012) Metal accumulation in the tissues of grass carps (Ctenopharyngodon idellus) from fresh water around a copper mine in Southeast China. Environ Monit Assess 184, 4289-4299.

20. Martinez-Alvarez RM, Morales AE \& Sanz A (2005) Antioxidant defenses in fish: biotic and abiotic factors. Rev Fish Biol Fisher 15, 75-88.

21. Wu P, Jiang W, Liu Y, et al. (2014) Effect of choline on antioxidant defenses and gene expressions of Nrf2 signaling molecule in the spleen and head kidney of juvenile Jian carp (Cyprinus carpio var. Jian). Fish Shellfish Immunol 38, 374-382.

22. Jiang J, Zheng T, Zhou X, et al. (2009) Influence of glutamine and vitamin $\mathrm{E}$ on growth and antioxidant capacity of fish enterocytes. Aquacult Nutr 15, 409-414.

23. Chen J, Zhou X, Feng L, et al. (2009) Effects of glutamine on hydrogen peroxide-induced oxidative damage in intestinal epithelial cells of Jian carp (Cyprinus carpio var. Jian). Aquaculture 288, 285-289.

24. Kohen R \& Nyska A (2002) Invited review: oxidation of biological systems: oxidative stress phenomena, antioxidants, redox reactions, and methods for their quantification. Toxicol Pathol 30, 620-650.

25. Muthusamy VR, Kannan S, Sadhaasivam K, et al. (2012) Acute exercise stress activates Nrf2/ARE signaling and promotes antioxidant mechanisms in the myocardium. Free Radic Biol Med 52, 366-376.

26. Ma Q (2013) Role of Nrf2 in oxidative stress and toxicity. Annu Rev Pharmacol 53, 401-426.

27. Jiang WD, Liu Y, Hu K, et al. (2014) Copper exposure induces oxidative injury, disturbs the antioxidant system and changes the Nrf2/ARE (CuZnSOD) signaling in the fish brain: protective effects of myo-inositol. Aquat Toxicol 155, 301-313.

28. Chen S, Zou L, Li L, et al. (2013) The protective effect of glycyrrhetinic acid on carbon tetrachloride-induced chronic liver fibrosis in mice via upregulation of Nrf2. PLOS ONE $\mathbf{8}$, e53662.

29. Shiau S \& Su S (2005) Juvenile tilapia (Oreochromis niloticus $\times$ Oreochromis aureus) requires dietary myo-inositol for maximal growth. Aquaculture 243, 273-277.

30. Wang B, Feng L, Jiang W, et al. (2015) Copper-induced tight junction mRNA expression changes, apoptosis and antioxidant responses via NF- $\mathrm{BB}$, TOR and Nrf2 signaling 
molecules in the gills of fish: preventive role of arginine. Aquat Toxicol 158, 125-137.

31. Basic D, Schjolden J, Krogdahl A, et al. (2013) Changes in regional brain monoaminergic activity and temporary down-regulation in stress response from dietary supplementation with l-tryptophan in Atlantic cod (Gadus morbua). Br J Nutr 109, 2166-2174.

32. Enamorado AD, Martins AC, Flores JA, et al. (2015) Biochemical responses over time in common carp Cyprinus carpio (Teleostei, Cyprinidae) during fed supplementation with alpha-lipoic acid. Comp Biochem Physiol A Mol Integr Physiol 188, 9-16.

33. Booth C \& O'Shea J (2002) Isolation and culture of intestinal epithelial cells. In Culture of Epithelial Cells, pp. 303-335 [R Freshney and M Freshney, editors]. New York: Wiley-Liss Inc.

34. Jiang J (2005) Effects of glutamine on the growth and metabolism of enterocytes in Jian carp (Cyprinus carpio var. Jian). Sichuan Agricultural University.

35. Krogdahl A, Bakke Mckellep AM \& Baeverfjord G (2003) Effects of graded levels of standard soybean meal on intestinal structure, mucosal enzyme activities, and pancreatic response in Atlantic salmon (Salmo salar L.). Aquacult Nutr 9, 361-371.

36. Ahn SK, Hong S, Park YM, et al. (2012) Protective effects of agmatine on lipopolysaccharide-injured microglia and inducible nitric oxide synthase activity. Life Sci 91, 1345-1350.

37. Tang SE, Wu CP, Wu SY, et al. (2014) Stanniocalcin-1 ameliorates lipopolysaccharide-induced pulmonary oxidative stress, inflammation, and apoptosis in mice. Free Radic Biol Med 71, 321-331.

38. Mulier B, Rahman I, Watchorn T, et al. (1998) Hydrogen peroxide-induced epithelial injury: the protective role of intracellular nonprotein thiols (NPSH). Eur Respir $J$ 11, 384-391

39. Zhang X, Zhu Y, Cai L, et al. (2008) Effects of fasting on the meat quality and antioxidant defenses of market-size farmed large yellow croaker (Pseudosciaena crocea). Aquaculture 280, 136-139.

40. Armenteros M, Heinonen M, Ollilainen V, et al. (2009) Analysis of protein carbonyls in meat products by using the DNPH-method, fluorescence spectroscopy and liquid chromatography-electrospray ionisation-mass spectrometry (LC-ESI-MS). Meat Sci 83, 104-112.

41. Pandey S, Parvez S, Ansari RA, et al. (2008) Effects of exposure to multiple trace metals on biochemical, histological and ultrastructural features of gills of a freshwater fish, Channa punctata Bloch. Chem Biol Interact 174, 183-192.

42. Jiang WD, Feng L, Liu Y, et al. (2009) Myo-inositol prevents oxidative damage, inhibits oxygen radical generation and increases antioxidant enzyme activities of juvenile Jian carp (Cyprinus carpio var. Jian). Aquacult Res 40, 1770-1776.

43. Bradford MM (1976) A rapid and sensitive method for the quantitation of microgram quantities of protein utilizing the principle of protein-dye binding. Anal Biochem 72, 248-254.

44. Jiang J, Shi D, Zhou XQ, et al. (2015) In vitro and in vivo protective effect of arginine against lipopolysaccharide induced inflammatory response in the intestine of juvenile Jian carp (Cyprinus carpio var. Jian). Fish Shellfish Immunol $\mathbf{4 2}$, 457-464.

45. Lall SP (2003) 5 - the minerals. In Fish Nutrition, 3rd ed. pp. 259-308 [JE Halver and RW Hardy, editors]. San Diego, CA: Academic Press.
46. Bopp SK, Abicht HK \& Knauer K (2008) Copper-induced oxidative stress in rainbow trout gill cells. Aquat Toxicol 86, 197-204.

47. Chung MJ, Walker PA, Brown RW, et al. (2005) Z-mediated gene expression offers protection against $\mathrm{H}_{2} \mathrm{O}_{2}$-induced cytotoxicity. Toxicol Appl Pharmacol 205, 225-236.

48. Iizuka M, Sasaki K, Hirai Y, et al. (2007) Morphogenic protein epimorphin protects intestinal epithelial cells from oxidative stress by the activation of EGF receptor and MEK/ERK, PI3 kinase/Akt signals. Am J Physiol Gastrointest Liver Physiol 292, G39-G52.

49. Jiang J, Shi D, Zhou XQ, et al. (2015) Vitamin D inhibits lipopolysaccharide-induced inflammatory response potentially through the toll-like receptor 4 signalling pathway in the intestine and enterocytes of juvenile Jian carp (Cyprinus carpio var. Jian). Br J Nutr 114, 1560-1568.

50. Villanueva J, Vanacore R, Goicoechea O, et al. (1997) Intestinal alkaline phosphatase of the fish Cyprinus carpio: regional distribution and membrane association. J Exp Zool 279, 347-355.

51. Kohen R \& Nyska A (2002) Oxidation of biological systems: oxidative stress phenomena, antioxidants, redox reactions, and methods for their quantification. Toxicol Pathol 30, 620-650.

52. Valko M, Morris H \& Cronin MT (2005) Metals, toxicity and oxidative stress. Curr Med Chem 12, 1161-1208.

53. Li M, Hu C, Zhu Q, et al. (2006) Copper and zinc induction of lipid peroxidation and effects on antioxidant enzyme activities in the microalga Pavlova viridis (Prymnesiophyceae). Chemosphere 62, 565-572.

54. Winston GW \& Di Giulio RT (1991) Prooxidant and antioxidant mechanisms in aquatic organisms. Aquat Toxicol 19, 137-161.

55. David M, Munaswamy V, Halappa R, et al. (2008) Impact of sodium cyanide on catalase activity in the freshwater exotic carp, Cyprinus carpio (Linnaeus). Pest Biochem Phys 92, 15-18.

56. Cabrini L, Bergami R, Fiorentini D, et al. (1998) Vitamin $\mathrm{B}_{6}$ deficiency affects antioxidant defences in rat liver and heart. Biochem Mol Biol In 46, 689-697.

57. Sies H (1999) Glutathione and its role in cellular functions. Free Radical Bio Med 27, 916-921.

58. Puntel RL, Roos DH, Grotto D, et al. (2007) Antioxidant properties of Krebs cycle intermediates against malonate pro-oxidant activity in vitro: a comparative study using the colorimetric method and HPLC analysis to determine malondialdehyde in rat brain homogenates. Life Sci $\mathbf{8 1}, 51-62$.

59. Jiang W, Liu Y, Jiang J, et al. (2015) Copper exposure induces toxicity to the antioxidant system via the destruction of Nrf2/ ARE signaling and caspase-3-regulated DNA damage in fish muscle: amelioration by myo-inositol. Aquat Toxicol 159, 245-255.

60. Wang T, Long X, Liu Z, et al. (2015) Effect of copper nanoparticles and copper sulphate on oxidation stress, cell apoptosis and immune responses in the intestines of juvenile Epinephelus coioides. Fish Shellfish Immunol 44, 674-682.

61. Garcia SF, de Lima BC, Tie OE, et al. (2008) Antioxidant defenses and biochemical changes in pacu (Piaractus mesopotamicus) in response to single and combined copper and hypoxia exposure. Comp Biochem Physiol $C$ Toxicol Pharmacol 147, 43-51. 